\title{
Fractionation and Mobility of Thallium in Volcanic Ashes after Eruption of Eyjafjallajökull (2010) in Iceland
}

\author{
Bozena Karbowska ${ }^{1} \cdot$ Wlodzimierz Zembrzuski ${ }^{1}$
}

Received: 23 November 2015/Accepted: 13 May 2016/Published online: 21 May 2016

(c) The Author(s) 2016. This article is published with open access at Springerlink.com

\begin{abstract}
Volcanic ash contains thallium (Tl), which is highly toxic to the biosphere. The aim of this study was to determine the $\mathrm{Tl}$ concentration in fractions of volcanic ash samples originating from the Eyjafjallajökull volcano. A sequential extraction scheme allowed for a study of element migration in the environment. Differential pulse anodic stripping voltammetry using a flow measuring system was selected as the analytical method to determine $\mathrm{Tl}$ content. The highest average content of $\mathrm{Tl}$ in volcanic ash was determined in the fraction entrapped in the aluminosilicate matrix $\left(0.329 \mu \mathrm{g} \mathrm{g}^{-1}\right)$, followed by the oxidizable fraction $\left(0.173 \mu \mathrm{g} \mathrm{g}^{-1}\right)$. The lowest content of $\mathrm{Tl}$ was found in the water soluble fraction $\left(0.001 \mu \mathrm{g} \mathrm{g}^{-1}\right)$; however, this fraction is important due to the fact that $\mathrm{Tl}$ redistribution among all the fractions occurs through the aqueous phase.
\end{abstract}

Keywords FIA-DPASV $\cdot$ Mobility $\cdot$ Sequential extraction $\mathrm{BCR} \cdot \mathrm{Tl} \cdot$ Toxicity $\cdot$ Volcanic ash

Volcanic eruptions are one of the main sources of heavy metals in the environment. The spreading of volcanic ash over a large area is a major problem, which leads to a number of health-related risks to humans, animals and plants. Deposition of volcanic dust on the surface of plant leaves and migration of ash with rain water into the soil may lead to the poisoning of the environment and is a direct threat to livestock (Dawson et al. 2010).

Bozena Karbowska

bozena.karbowska@put.poznan.pl

1 Institute of Chemistry and Technical Electrochemistry, Poznan University of Technology, ul.Berdychowo 4, 61-138 Poznan, Poland
The eruption of Eyjafjallajökull volcano was one of the largest in Europe in recent years. The effects of the eruption were recorded in various places in Europe up to the present day. The crater was inactive during the last 187 years. However, on March 20, 2010, the lava began to flow and there were several series of small eruptions which ejected volcanic ash into the atmosphere. After a brief pause the eruption began again on April 14, 2010, with much more intensity, spreading volcanic ash into the atmosphere up to a height of $9 \mathrm{~km}$. Volcanic ash formed during the volcanic eruption, which consisted of small particles of stone powder with a diameter less than $2 \mathrm{~mm}$, resulting in direct damage to the local ecosystem, but also causing serious disruptions in air traffic. It was proven that the westerly winds spread volcanic ash up to a distance of $3000 \mathrm{~km}$ from Iceland (Dawson et al. 2010; Gao et al. 2011). The ash began to fall in the south-eastern part of Iceland on April 14. The spread reached Norway and the United Kingdom on the following day (Gíslason and Alfredsson 2010; Wunderman et al. 2011; Gislason et al. 2011).

Several studies showed that the layer of dust deposited on the soil mainly included aluminum, silicon and oxygen. Compounds such as silicon dioxide and silica can cause disease in miners and stonemasons, which is called silicosis. Other components, which were present at notably excessive concentrations, included magnesium, fluoride, and heavy metals such as iron, nickel, chromium, cadmium and mercury (Gíslason and Alfredsson 2010; Maynard et al. 2010).

Although there is little information regarding this subject, part of the volcanic ash also contained thallium (Tl). Thallium is a soft, malleable metal, with a blue-white colored surface similar in appearance to lead. Due to the similarity of alkali metals, it can replace potassium in 
biological systems. As a result, Tl can interfere with cellular metabolism by reducing the activity of important enzymes and coenzymes. Furthermore, it is characterized by high toxicity to aquatic organisms, humans and other animals (Dmowski and Badurek 2001; Dmowski et al. 2002; Krasnodębska-Ostręga et al. 2005). Thallium (I) compounds with high solubility in water are readily absorbed through the skin. Thallium is considered as probably carcinogenic to humans (Emsley 2006). It is highly toxic to the biosphere, with toxicity higher than that of mercury, cadmium, lead and copper (Peter and Viraraghavan 2005). Moreover, it exhibits mutagenic, carcinogenic and teratogenic properties. Stomach and intestinal ulcers, alopecia, and polyneuropathy are considered classic syndromes of $\mathrm{Tl}$ poisoning (Xiao et al. 2007). Ingestion of more than $1.5 \mathrm{mg}$ per $\mathrm{kg}$ of body weight (approximately $0.2-1 \mathrm{~g}$ ) can be fatal. Thallium salts are rapidly and almost completely absorbed through the gastrointestinal route. No symptoms are evident, at least at the beginning of intoxication, thereby preventing accurate diagnosis of early $\mathrm{Tl}$ poisoning, and thus the application of appropriate therapeutic measures (Lech and Sadlik 2007). Skin contact, ingestion, and introduction into the respiratory tract are very dangerous and cause irritation of the gastrointestinal tract and nervous system disorders. Thallium poisoning can cause changes in blood chemistry, liver, kidney, intestine and testis tissue. Additionally, it results in abdominal pain, diarrhea and tingling of the extremities. Due to the notable element of risk, the content of thallium is systematically measured in environmental samples (e.g. river water or groundwater) in order to prevent its uncontrolled spread (Lukaszewski et al. 2010; Wojtkowiak et al. 2016).

Mobility, toxicity and bioavailability of metals depends mainly on the chemical form in which they occur, and how they bind to the soil matrix. Metals in uncontaminated soils mainly form silicates and primary minerals, resulting in a relatively immobile form (Yang et al. 2005). In soils already contaminated with metals additional metal ions are more mobile, due to their weaker binding to other components of the soil (Lukaszewski et al. 2003). Determination of total metal content in samples provides information which allows for an assessment of the degree of soil contamination associated with the presence of metals. The total concentration of $\mathrm{Tl}$ in selected elements of the environment is only an initial measure for the estimation of health hazards associated the presence of this compound. However, only the study of distribution of metals in the appropriate fractions allows for the determination of possible effects on the environment (Vaněk et al. 2011; Vaněk et al. 2010a, b). It is important to establish the mobility of Tl. Such data may be obtained by utilization of sequential extraction. Previous reports indicated that the major fraction of $\mathrm{Tl}$ was entrapped in the aluminosilicate parent matter (Lukaszewski et al. 2012) and became immobile in the environment. Therefore, it was hypothesized that a similar effect would be observed in case of volcanic ash originating from Eyjafjallajökull.

The aim of this study was to determine the Tl concentration in fractions of volcanic ash samples originating from the Eyjafjallajökull volcano. The number of reports dedicated to the determination of $\mathrm{Tl}$ in the environment is limited and the scale of associated health hazards is poorly understood. To the best of our knowledge this is the first study to characterize the fractions of $\mathrm{Tl}$ present in soil contaminated with volcanic ash.

\section{Materials and Methods}

The following apparatuses were used during the experiments: an ISM596D peristaltic pump (Ismatec, Jona, CH) with a flow rate of $2 \mathrm{~mL} / \mathrm{min}$, a PalmSens $3 \mu$-AUTOLAB ECOCHEMIE electrochemical analyzer (PalmSens, Utrecht, NL), a mercury film electrode based on epoxy resin impregnated graphite (which was used as a working electrode), a saturated calomel electrode (which was the reference electrode) and a platinum wire (which was the auxiliary electrode). Other laboratory equipment used during all measuring steps were: a $\mathrm{pH}$ meter, a magnetic stirrer, and a technical balance.

The solution for the electrolytic production of film consisted of $0.1 \mathrm{M}$ potassium nitrate and $0.05 \mathrm{mM} \mathrm{Tl}$ (I) nitrate. A starting solution of $0.2 \mathrm{M}$ EDTA was used to obtain an alkaline electrolyte solution of $0.05 \mathrm{M}$ EDTA and $0.1 \mathrm{M}$ ascorbic acid. Acetic acid $(0.1 \mathrm{M})$ was used in sequential extraction of soil samples for the determination of $\mathrm{Tl}$ in the carbonate fraction. Ammonium hydroxide $(0.1 \mathrm{M})$ was used for the determination of $\mathrm{Tl}$ compounds in the reducible fraction. A $1 \mathrm{M}$ ammonium acetate solution was used for the digestion of soil samples, during the determination of Tl. Hydrofluoric acid $(73 \%)$ was used to dissolve the sample and pre-stripping of volatile compounds. Afterwards the sample was treated with $65 \%$ nitric acid $(\mathrm{V})$ and $30 \%$ hydrogen peroxide. All chemical reactants were obtained from Sigma Aldrich (Poznan, PL). GBW 07401 Chinese soil, certified for total content of Tl $\left(1.0 \pm 2.0 \mu \mathrm{g} \times \mathrm{g}^{-1}\right)$ was used as reference material (Chinese National Standard Reference Materials, Beijing, $\mathrm{CN})$.

The research material was derived from volcanic ash originating from the volcano Eyjafjallajökull in Iceland. Four samples (A, B, C and D) were analyzed with three replicates per sample (a total of 12 measurements). The first part of samples was subjected to determination the total content of $\mathrm{Tl}$ in volcanic ash (the water soluble, acid 
soluble/exchangeable, reducible and oxidized fractions). The second part of samples, was mineralized before the process of sequential extraction of $\mathrm{Tl}$ in volcanic ashes (the fraction entrapped in parent matter). Prior to the determination, the samples the volcanic ash were subjected to a granulometric analysis with the use of set of pre-defined sieves. The results of the analysis are presented in Table 1.

The use of Community Bureau of Reference (BCR) extraction scheme (Fig. 1) was employed as the analytical method for determination of $\mathrm{Tl}$ in subsequent fractions (Vaněk et al. 2010a, b). The water soluble fraction was obtained by treating $0.25 \mathrm{~g}$ of volcanic ash sample with $10 \mathrm{~mL}$ of demineralized water in a $100 \mathrm{~mL}$ conical flask and shaken at $25^{\circ} \mathrm{C}$ for $16 \mathrm{~h}$. The mixture was centrifuged and the solution was transferred to a $25 \mathrm{~mL}$ volumetric flask. Afterwards, $6.25 \mathrm{~mL}$ of $0.2 \mathrm{M}$ EDTA was added and the flask supplemented with water to the mark.

The acid soluble/exchangeable fraction was obtained by treating the residual sample from the previous step with 10 $\mathrm{mL}$ of $0.11 \mathrm{M}$ acetic acid in a $100 \mathrm{~mL}$ conical flask and shaken at $25^{\circ} \mathrm{C}$ for $16 \mathrm{~h}$. The mixture was then centrifuged and the solution transferred to a $25 \mathrm{~mL}$ volumetric flask. The sediment sample was treated with $2.5 \mathrm{~mL}$ of water and shaken for $10 \mathrm{~min}$, then centrifuged and the solution was added to the solution of the fraction. The $\mathrm{pH}$ of the solution was adjusted to $4.5 \%$ with $25 \%$ aqueous ammonia solution or $2 \mathrm{M}$ nitric acid. Afterwards $6.25 \mathrm{~mL}$ of $0.2 \mathrm{M}$ EDTA was added and the flask supplemented with water to the mark.

The reducible fraction was obtained by treating the residual sample from the previous step with $10 \mathrm{~mL}$ of $0.1 \mathrm{M}$ hydroxylamine hydrochloride, followed by adjusting the $\mathrm{pH}$ to 2 with $2 \mathrm{M}$ nitric acid in a $100 \mathrm{~mL}$ conical flask and shaking at $25^{\circ} \mathrm{C}$ for $16 \mathrm{~h}$. The mixture was centrifuged and the solution was transferred to a $25 \mathrm{~mL}$ volumetric flask. The sediment sample was treated with $2.5 \mathrm{~mL}$ of water, shaken for $10 \mathrm{~min}$, and then centrifuged. The solution was added to the solution of the fraction. Afterwards, $2.5 \mathrm{~mL}$ of $1 \mathrm{M}$ ascorbic acid was added to the joint solutions. The $\mathrm{pH}$ was adjusted to 4.5 with $25 \%$ aqueous ammonia solution or $2 \mathrm{M}$ nitric acid, then $6.25 \mathrm{~mL}$ of 0.2 M EDTA was added and the flask filled with water.

Table 1 Granulometric analysis of the studied volcanic ash samples

\begin{tabular}{lc}
\hline Fraction size $(\mathrm{mm})$ & Ratio $(\%)$ \\
\hline $0.5-2$ & 0.1 \\
$0.25-0.5$ & 16.7 \\
$0.1-0.25$ & 29.5 \\
$0.05-0.1$ & 39.6 \\
$0.02-0.05$ & 13.2 \\
$<0.02$ & 0.9 \\
\hline
\end{tabular}

The oxidized fraction was obtained by treating the residual sample from the previous step with $2.5 \mathrm{~mL}$ of $30 \%$ hydrogen peroxide in a $100 \mathrm{~mL}$ conical flask, and then shaking at $25^{\circ} \mathrm{C}$ for $1 \mathrm{~h}$ and at $85^{\circ} \mathrm{C}$ for $1 \mathrm{~h}$. The mixture was evaporated to the volume of $1-2 \mathrm{~mL}$. The next $2.5 \mathrm{~mL}$ portion of $30 \%$ hydrogen peroxide was added, the mixture shaken at $85^{\circ} \mathrm{C}$ for $1 \mathrm{~h}$, and the mixture evaporated until dry. The residue was treated with $12.5 \mathrm{~mL}$ of $1 \mathrm{M}$ ammonium acetate and the $\mathrm{pH}$ value was adjusted to 2 with $2 \mathrm{M}$ nitric acid, and then shaken at $25^{\circ} \mathrm{C}$ for $16 \mathrm{~h}$. The mixture was centrifuged and the solution transferred into a $25 \mathrm{~mL}$ volumetric flask. The sediment sample was treated with $2.5 \mathrm{~mL}$ of water, shaken for $10 \mathrm{~min}$ and centrifuged. The solution was added to the solution of the fraction. Afterwards $2.5 \mathrm{~mL}$ of $1 \mathrm{M}$ ascorbic acid was added to the joint solutions. The $\mathrm{pH}$ was adjusted to 4.5 with $25 \%$ aqueous ammonia solution or $2 \mathrm{M}$ nitric acid, followed by the addition of $6.25 \mathrm{~mL}$ of $0.2 \mathrm{M}$ EDTA. Water was then added to fill the flask to its mark.

The fraction entrapped in parent matter was obtained by placing a dried $0.25 \mathrm{~g}$ sample of volcanic ash into a Teflon beaker, and digesting it by adding $2 \mathrm{~mL}$ of $73 \%$ hydrofluoric acid. After $2 \mathrm{~h}, 0.6 \mathrm{~mL}$ of hydrofluoric acid were added. The solution was heated until evaporation, then $1 \mathrm{ml}$ of $67 \%$ nitric acid and $2.5 \mathrm{~mL}$ of $30 \%$ hydrogen peroxide in portions of $0.5 \mathrm{~mL}$ were added. After evaporation of the solution, another portion of $1 \mathrm{~mL}$ of nitric acid was added. Afterwards, it was covered with a watch glass and heated for $3 \mathrm{~h}$. The soil solution was then filtered. The filtrate was mixed with $2.5 \mathrm{~mL}$ of $1 \mathrm{M}$ ascorbic acid and $6.25 \mathrm{~mL}$ of $0.2 \mathrm{M}$ EDTA. Then, after adjusting the $\mathrm{pH}$ value to $4.5 \mathrm{using}$ ammonium solution, the solution was transferred to a $25 \mathrm{~mL}$ flask and supplemented with water.

The obtained solution was used to determine the total content of $\mathrm{Tl}$ in the volcanic ash using flow injection analysis - differential pulse anodic stripping voltammetry (FIA-DPASV) (Lukaszewski et al. 2010). Determination of Tl by FIA-DPASV was carried out according to the following protocol (Fig. 2). Peristaltic pump with forced flow was used with constant flow rate of $2 \mathrm{~mL} / \mathrm{min}$. The sample was aspirated from the $10 \mathrm{~mL}$ sample vial into the measuring vial, which contained three electodes: a mercury film electrode based on epoxy resin impregnated graphite was used as a working electrode, a saturated calomel electrode was the reference electrode and platinum wire was the auxiliary electrode (Lukaszewski and Zembrzuski 1992, 2010).

The use of a flow measuring system made it possible to avoid the problem of depletion of the sample solution caused by the limited capacity of the measuring vessel and allowed for the circulation of the electrolyte. A 0.05 M EDTA solution was used as the base electrolyte. 
Fig. 1 Community Bureau of Reference (BCR) extraction scheme

Fig. 2 Flow-injection voltammetric system. $P C$ personal computer, $M F E$ mercury film electrode, $S C E$ saturated calomel electrode
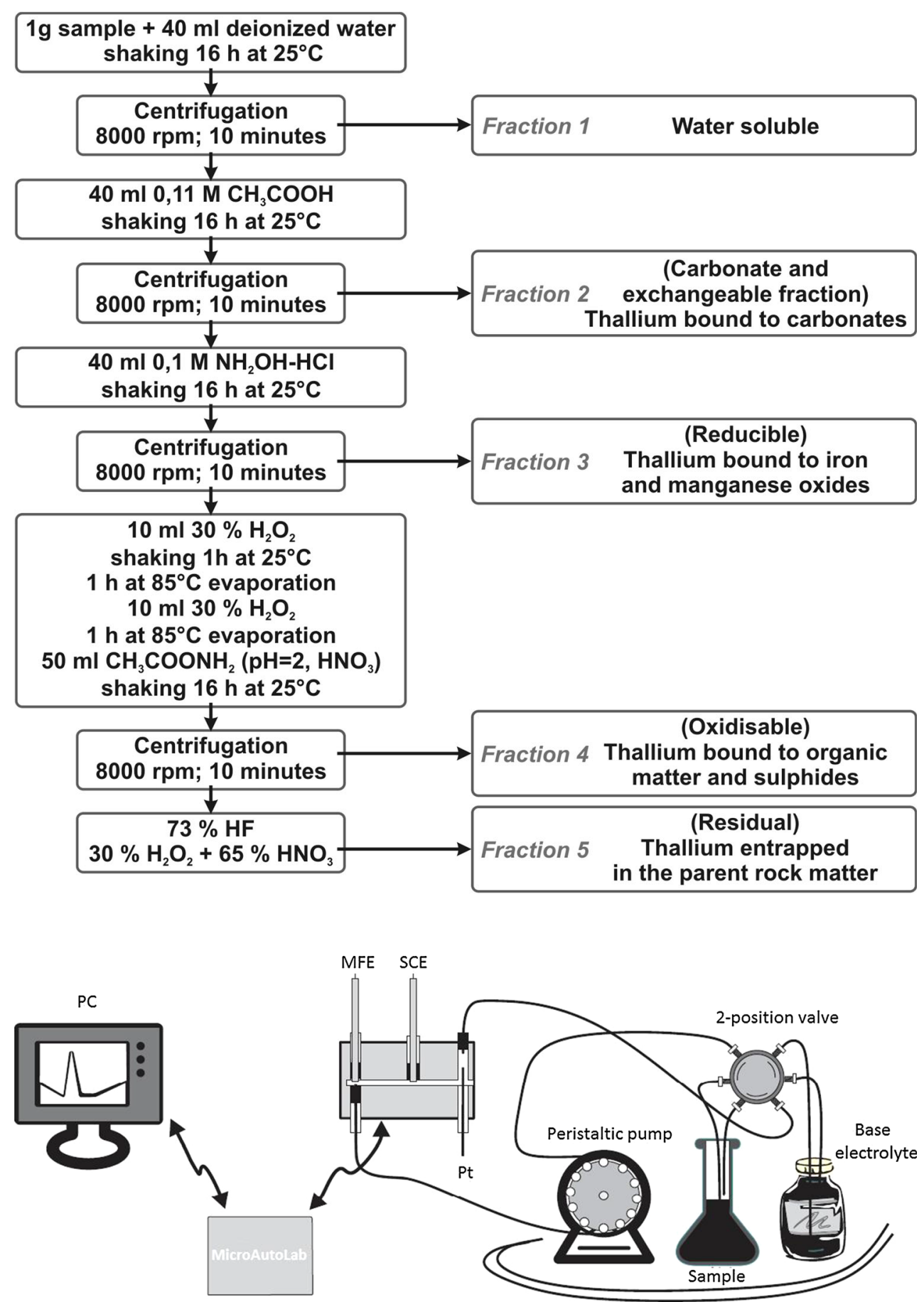

Electrochemical device
The operating parameters (i.e., concentration, potential and time) for the measurements were selected based on a series of previous studies (Jakubowska et al. 2008).

Determination of peak height, which depended on the potential of $\mathrm{Tl}$ concentration, allowed for the selection of $-0.9 \mathrm{~V}$ as the optimum potential for the study. The dependence between the peak concentration of $\mathrm{Tl}$ and time allowed for determination of time necessary for sample concentration to achieve a readily measurable amount in the subsequent analysis. The resulting linear dependence of peak height on its concentration of $\mathrm{Tl}$ showed no signs of depletion of $\mathrm{Tl}$.

After the mineralization procedure, the concentration of $\mathrm{Tl}$ in the samples (A, B, C, and D) was estimated on the basis of several standard additions (typically three additions). All measurements were carried out in triplicate 
(three independent measurements for samples A, B, C, and D), which were used to calculate standard deviation values (based on a total of 12 measurements).

In order to control the analytical quality, the precision of the method was determined with a reference material - soil GBW 07401. Nine independent trials were conducted for the reference material in order to determine the $\mathrm{Tl}$ content. The average content of $\mathrm{Tl}$ was at $0.90 \pm 0.14 \mu \mathrm{g} / \mathrm{g}$ (with a minimum of 0.76 and a maximum of $1.1 \mu \mathrm{g} / \mathrm{g}$ ). The recovery of $\mathrm{Tl}$ was at $90 \%$.

\section{Results and Discussion}

Volcanic ash sediments were processed in accordance with the modified BCR procedure. The results are shown in Table 2. Additionally, total $\mathrm{Tl}$ concentration was determined independently in the investigated samples.

The results shown in Fig. 3 indicate that $\mathrm{Tl}$ formed a deposit on the electrode surface. The conclusion based on the performed investigation was that the majority of $\mathrm{Tl}$ in the investigated volcanic ash sediment samples (63\%) was entrapped in the alumosilicate parent matter; i.e., it was entirely unavailable (Table 1). Only total destruction of this residual fraction with hydrofluoric acid makes this $\mathrm{Tl}$ available. This conclusion strongly supported the hypothesis that $\mathrm{Tl}$ would be mainly entrapped in residual parent matter. This is a significant observation; the potential risk of the toxic effect of $\mathrm{Tl}$ is strongly limited due to low mobility. The mobile $\mathrm{Tl}$ i.e. $\mathrm{Tl}$ contained in four basic ally soluble sediment fractions comprised only $36 \%$ of the total content. The order for concentrations of $\mathrm{Il}$ in the four mobile sediment fractions was: water soluble fraction $<$ exchangeable fraction $<$ reducible fraction $<$ oxidizable fraction. It is worth emphasizing that the combined
$\mathrm{Tl}$ concentration in the most mobile water soluble and acid soluble/exchangeable fractions was very small and varied between $0.23 \%$ and $0.77 \%$ of the total $\mathrm{Tl}$ concentration in the investigated samples.

The water soluble fraction varies from 0.0007 to $0.0016 \mu \mathrm{g} \mathrm{g}^{-1}$. Determination of the water fraction is important due to the fact that $\mathrm{Tl}$ redistribution among all the fractions occurs through the aqueous phase (Karbowska et al. 2014).

The acid soluble/exchange able fraction varied from 0.004 to $0.005 \mu \mathrm{g} \mathrm{g}^{-1}$. The fraction of ion exchange/carbonate dissolution indicates an acidic environment. The exchangeable fraction includes related metals in soil solution and the associated constant fraction of the soil on the basis of physical and chemical adsorption and ion exchange sorption. This fraction mainly includes metals that are retained on the soil surface by relatively weak electrostatic forces, and metals that may be released during ion exchange. It usually accounts for about $2 \%$ of the total content of elements present in the soil. The carbonate fraction includes heavy metal carbonates and forms adsorbed with calcium carbonate, sulphates and phosphates (Filgueiras et al. 2002). This fraction is very sensitive to changes of $\mathrm{pH}$, which is why it is important that this stage of extraction was carried out at pH5 (Kuokkanena et al. 2006).

The reducible fraction varies from 0.01 to $0.02 \mu \mathrm{g} \mathrm{g}^{-1}$. It describes the fraction of reducible metal oxides bound with iron and manganese hydroxides. The fraction associated with oxides of iron and manganese includes metals absorbed to hydrated oxides of iron and manganese and in the form of thin layers surrounding minerals (this fraction is unstable with a deficit of oxygen or a change in redox potential). Iron and manganese oxides can strongly bind metals. They are also a component of the sorption complex.

Table $2 \mathrm{Tl}$ concentration $\left(\mu \mathrm{g} \mathrm{g}^{-1}\right.$ ) in volcanic ash fractions (obtained by sequential extraction and by total independent measurement

\begin{tabular}{|c|c|c|c|c|c|c|c|}
\hline \multirow[t]{2}{*}{ Ash sample } & \multicolumn{5}{|l|}{ Fraction } & \multirow[t]{2}{*}{ Total } & \multirow{2}{*}{$\begin{array}{l}\text { Total independent } \\
\text { measurment }\end{array}$} \\
\hline & $\begin{array}{l}\text { Water } \\
\text { soluble }\end{array}$ & $\begin{array}{l}\text { Acid soluble/ } \\
\text { exchangeable }\end{array}$ & Reducible & Oxidizable & $\begin{array}{l}\text { Entrapped in parent } \\
\text { matter }\end{array}$ & & \\
\hline A & 0.0008 & 0.004 & 0.01 & 0.201 & 0.359 & 0.575 & 0.499 \\
\hline B & 0.0007 & 0.005 & 0.02 & 0.159 & 0.365 & 0.550 & 0.520 \\
\hline $\mathrm{C}$ & 0.0016 & 0.004 & 0.01 & 0.146 & 0.257 & 0.419 & 0.441 \\
\hline $\mathrm{D}$ & 0.0016 & 0.004 & 0.01 & 0.187 & 0.335 & 0.538 & 0.442 \\
\hline Blank & 0.00008 & 0.0001 & 0.0008 & 0.0001 & 0.0003 & & 0.0014 \\
\hline Average & 0.0012 & 0.004 & 0.0125 & 0.173 & 0.329 & 0.520 & 0.471 \\
\hline SD & 0.0004 & 0.001 & 0.005 & 0.025 & 0.049 & & 0.046 \\
\hline $\begin{array}{l}\text { Percent of Total } \\
\mathrm{Tl}\end{array}$ & 0.23 & 0.77 & 2.4 & 33.27 & 63.27 & & \\
\hline
\end{tabular}


Fig. 3 Energy dispersive spectra (left) and scanning electron micrograph of electrode surface (right)

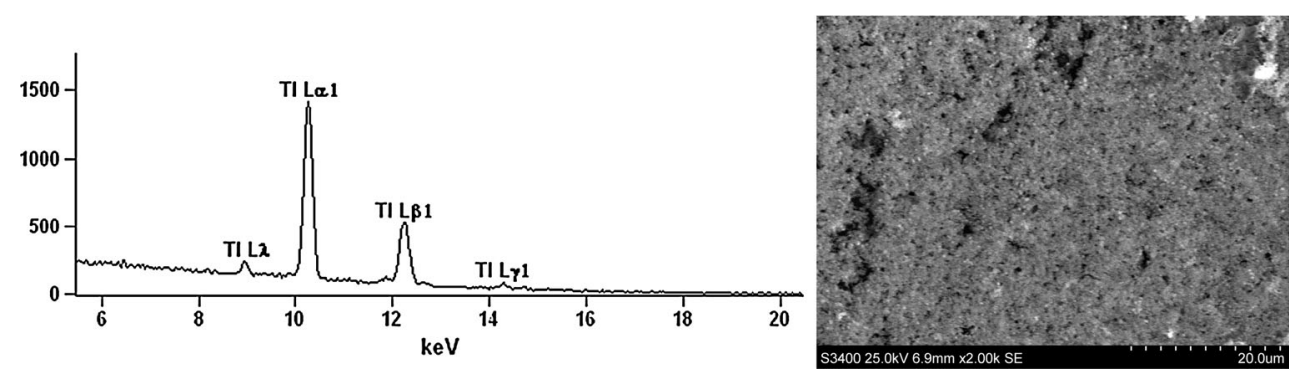

The most effective reagents that are likely to capture the total metal content associated with iron and manganese oxides contain both a reducing reagent and a ligand capable of maintaining the released ions in dissolved form. The effectiveness of the reagent depends on its reduction potential (Jakubowska et al. 2007). Crowding consists of one or several stages, involving the separation of amorphous or crystalline forms of iron and manganese oxides (Lukaszewski and Zembrzuski 1992).

Oxidizable fraction varies from 0.146 to $0.201 \mu \mathrm{g} \times \mathrm{g}^{-1}$. The oxidizable fraction provides information regarding the metal associated with organic compounds and sulfides, which is the form of $\mathrm{Tl}$ released into the environment under oxidative conditions (Lukaszewski and Zembrzuski 1992). This fraction includes metals associated with various forms of organic matter, mainly humic and fulvic acids and sulfides. The elements may interact with soil organic matter, (i.e. humic substances) and become entrapped in the soil matrix, depending on the environmental conditions (e.g. the $\mathrm{pH}$ ) (Varrault and Bermond 2002).

The fraction of $\mathrm{Tl}$ entrapped in the parent mater varies from 0.257 to $0.365 \mu \mathrm{g} \mathrm{g}^{-1}$. Determination of $\mathrm{Tl}$ content in the residual fraction is important in evaluating the overall balance of $\mathrm{Tl}$ in all fractions. This fraction was compared with the summary concentration of $\mathrm{Tl}$. Determination of the residual fraction was obtained after treatment of the soil sample with strong acid, which ensures accurate results according to the results of previous studies (Lukaszewski et al. 2010).

The total concentration of $\mathrm{Tl}$ determined in the volcanic ashes $\left(0.4-0.52 \mu \mathrm{g} \mathrm{g}^{-1}\right)$ was two times higher compared to that in Tamar estuarine sediments in England (0.08-0.22 $\mu \mathrm{g} \mathrm{g}^{-1}$ ) (Anagboso et al. 2013). The established concentrations range was similar to that reported for soil floodplain terraces in Poland (0.38-0.44 $\mathrm{gg} \mathrm{g}^{-1}$ ) (Jakubowska et al. 2007), tsunami sediments in Thailand (0.38$\left.1.08 \mu \mathrm{g} \times \mathrm{g}^{-1}\right)$ (Lukaszewski et al. 2012), soils in the Czech Republic (0.43-0.79 $\mu \mathrm{g} \mathrm{g}^{-1}$ ) (Vaněk et al. 2010a, b), as well as soils derived from magmatic rocks (0.32-1.69 $\left.\mu \mathrm{g} \mathrm{g}^{-1}\right)$, metamorphic rocks $\left(0.26-1.0 \mu \mathrm{g} \mathrm{g}^{-1}\right)$, plastic rocks $\left(0.04-0.88 \mu \mathrm{g} \mathrm{g}^{-1}\right)$ and calcareous rocks (0.11-21.6 $\mu \mathrm{g} \mathrm{g}^{-1}$ ) in France (Tremel et al. 1997).

The Community Bureau of Reference (BCR) procedure (Vaněk et al. 2010a, b) allowed for an evaluation of how the soil metal might behave under the influence of changing environmental conditions. Depending on their forms metals are more or less mobile and thus bioavailable. Assessment of the behavior of heavy metals in soils should no longer be based only on total heavy metal content diagnosis and characterization of various forms/fractions of a given element is also necessary. Most of the standards for the maximum concentrations of heavy metals in both soils and water have continued to focus only on their total content. However, such data are insufficient for assessment of their activity and toxicity (Jeske and Gworek 2011).

The majority of $\mathrm{Tl}$ in the analysed volcanic ash (63\%) was entrapped in the alumosilicate parent matter, where it is entirely immobile. Only the total destruction of this residual fraction with hydrofluoric acid made this $\mathrm{Tl}$ available. This conclusion strongly supported the hypothesis that generally $\mathrm{Tl}$ would be mainly entrapped in an alumosilicate parent matter. Studies regarding the characterization of Eyjafjallajökull volcanic ash particles revealed the following bulk mineral composition: $\mathrm{SiO}_{2}(57.9 \%)$, $\mathrm{Al}_{2} \mathrm{O}_{3}(14.9 \%), \mathrm{FeO}(9.8 \%), \mathrm{CaO}(5.5 \%), \mathrm{Na}_{2} \mathrm{O}(5.0 \%)$, $\mathrm{MgO}(2.3 \%), \mathrm{K}_{2} \mathrm{O}(1.8 \%), \mathrm{TiO}_{2}(1.8 \%), \mathrm{P}_{2} \mathrm{O}_{5}(0.5 \%)$, $\mathrm{MnO}(0.2 \%)$ (Gislason et al. 2011). The high content of $\mathrm{SiO}_{2}$ and $\mathrm{Al}_{2} \mathrm{O}_{3}$ corresponds well with the findings regarding the entrapment of $\mathrm{Tl}$ in alumosilicate parent matter. Furthermore, the $2 \%$ content of $\mathrm{K}_{2} \mathrm{O}$ may be associated with the increased content of $\mathrm{Tl}$ in the tested samples, since the geochemical behaviour of $\mathrm{Tl}$ is analogous to that of K (Kabata-Pendias 2010). Tl exhibits high affinity to various minerals, which may lead to release of $\mathrm{K}$ from such minerals and inhibition of its activation energy.

In conclusion, it appears that the majority of the $\mathrm{Tl}$ originating from volcanic ash was not readily bioavailable in the environment. However, some plant species (such as white mustard, which is commonly used as livestock fodder) are capable of accumulating notable amounts of Tlbased compounds from soil, even with its limited mobility 
(Vaněk et al. 2010a, b). This phenomenon may be of importance in terms of environmental contamination, as uptake of $\mathrm{Tl}$ by such plants may lead to their direct introduction into the food chain.

Acknowledgments This study was supported by DS PB 31-314/ 2016. The authors are grateful to L. Lawniczak for assistance during the preparation of the manuscript.

Open Access This article is distributed under the terms of the Creative Commons Attribution 4.0 International License (http://creative commons.org/licenses/by/4.0/), which permits unrestricted use, distribution, and reproduction in any medium, provided you give appropriate credit to the original author(s) and the source, provide a link to the Creative Commons license, and indicate if changes were made.

\section{References}

Anagboso MU, Turner A, Braungardt CB (2013) Fractionation of thallium in the Tamar Estuary, south west England. J Geochem Explor 125:1-7

Dawson J, Delbos E, Hough R, Lumsdon D, Mayes B, Watson H (2010) Impacts of volcanic ash originating from the April 2010 eruption in Eyjafjallajökull (Iceland) on the natural resources of Scotland. The Macaulay Land Use Research Institute pp 1-2

Dmowski K, Badurek M (2001) Thallium contamination of selected biotic elements of ecosystems neighboring the zinc smelter in Bukowno. In: Gworek B, Mocka A (eds) The cycling of elements in nature. Instytut Ochrony Srodowiska, Warszawa, pp 19-24

Dmowski K, Kozakiewicz A, Kozakiewicz M (2002) Bioindykacyjne poszukiwania talu na terenach południowej Polski. Kosmos $51: 151-163$

Emsley J (2006) Thallium The Elements of murder A history of poison. Oxford University Press, Oxford, pp 326-327

Filgueiras A, Lavilla I, Bendicho C (2002) Chemical sequential extraction for metal partitioning in environmental solid samples. J Environ Monit 4:823-857

Gao F, Stanic S, Bergant K, Bolte T, Coren F, He TY, Hrabar A, Jerman J, Mladenovic A, Turšic J, Veberic D, Žibert M (2011) Monitoring presence and streaming patterns of Icelandic volcanic ash during its arrival to Slovenia. Biogeosciences 8:2351-2363

Gíslason SR, Alfredsson HA (2010) Sampling the volcanic ash from the Eyjafjallajökull Volcano. Iceland-a personal account. Elements 6:269-270

Gislason SR, Hassenkam T, Nedel S, Bovet N, Eiriksdottir ES, Alfredsson HA, Hem CP, Balogh ZI, Dideriksen K, Oskarsson N, Sigfusson B, Larsen G, Stipp SL (2011) Characterization of Eyjafjallajökull volcanic ash particles and a protocol for rapid risk assessment. Proc Natl Acad Sci USA 108(18):7307-7312

Jakubowska M, Pasieczna A, Zembrzuski W, Swit Z, Lukaszewski Z (2007) Thallium in fractions of soil formed on floodplain terraces. Chemosphere 66:611-618

Jakubowska M, Zembrzuski W, Lukaszewski Z (2008) Thallium determination at the single picomole per liter level by flowinjection differential-pulse anodic stripping voltammetry. Electroanal 20:1073-1077

Jeske A, Gworek B (2011) Methods used to assess bioavailability and mobility of heavy metals in soils. Ochr Środ i Zasob Natur 49:209-218

Kabata-Pendias A (2010) Trace elements in soils and plants, 4th edn. CRC Press, New York, pp 330-331
Karbowska B, Zembrzuski W, Jakubowska M, Wojtkowiak T, Pasieczna A, Lukaszewski Z (2014) Translocation and mobility of thallium from zinc-lead ores. J Geochem Explor 143:127-135

Krasnodębska-Ostręga B, Dmowski K, Stryjewska E, Golimowski J (2005) Determination of thallium and other toxic elements (As, $\mathrm{Cd}, \mathrm{Cu}, \mathrm{Mn}, \mathrm{Pb}, \mathrm{Se}, \mathrm{Sb}$, and $\mathrm{Zn}$ ) in water and sediment samples from the vicinity of the zinc-lead smelter in Poland. J Soils Sediments 5:71-73

Kuokkanena T, Pöykiö R, Nurmesniemic H, Rämö J (2006) Sequential leaching of heavy metals and sulfur in bottom ash and fly ash from the co-combustion of wood and peat at a municipal district heating plant. Chem Spec Bioavailab 18(4):131-142

Lech T, Sadlik JK (2007) Thallium intoxication in humans. Toxicol Lett 172:1-240

Lukaszewski Z, Zembrzuski W (1992) Determination of thallium in soils by flow-injection-differential pulse anodic stripping voltammetry. Talanta 39:221-227

Lukaszewski Z, Karbowska B, Zembrzuski W (2003) Determination of mobile thallium in soil by flow injection differential pulse anodic stripping voltammetry. Electroanal 15:5-6

Lukaszewski Z, Jakubowska M, Zembrzuski W, Karbowska B, Pasieczna A (2010) Flow-injection differential-pulse anodic stripping voltametry as a tool for thallium monitoring in the environment. Electroanal 22:17-18

Lukaszewski Z, Karbowska B, Zembrzuski W, Siepak M (2012) Thallium in fractions of sediments formed during the 2004 tsunami in Thailand. Ecotox Environ Saf 80:184-189

Maynard B, Mills I, Exley K (2010) Paper on the possible effects on health of exposure to volcanic ash and associated gases. Health Protection Agency, London SW1, England, pp 1-14

Peter ALJ, Viraraghavan T (2005) Thallium: a review of public health and environmental concerns. Environ Int 31:493-501

Tremel A, Masson P, Sterckeman T, Baize D, Mench D (1997) Thallium in French agrosystems- I. Thallium contents in arable soils. Environ Pollut 19:293-302

Vaněk A, Grygar T, Chrastny V, Tejnecky V, Drahota P, Komarek M (2010a) Assessment of the BCR sequential extraction procedure for thallium fractionation using synthetic mineral mixtures. J Hazard Mater 176:913-918

Vaněk A, Komárek M, Chrastny V, Bečka D, Mihaljevič M, Šebek O, Panušková G, Schusterová Z (2010b) Thallium uptake by white mustard (Sinapis alba L.) grown on moderately contaminated soils-Agro-environmental implications. J Hazard Mater 182: 303-308

Vaněk A, Komárek M, Vokurková P, Mihaljevič M, Šebek O, Panušková G, Chrastný V, Drábek O (2011) Effect of illite and birnessite on thallium retention and bioavailability in contaminated soils. J Hazard Mater 191:170-176

Varrault G, Bermond A (2002) Trace metal sorption ability of insolubilized humic acids. Environ Technol 23:421-428

Wojtkowiak T, Karbowska B, Zembrzuski W, Siepak M, Lukaszewski Z (2016) Miocene colored waters: a new significant source of thallium in the environment. $\mathrm{J}$ Geochem Explor 161:42-48

Wunderman R, Fela J, Herrick J, Sennert SK (2011). Eyjafjallajökull (Iceland) eruption ended in late 2010; sample of growing literature on the eruption. Volcanism Network 36 (4): 2-7

Xiao T, Guha J, Liu CQ, Zheng B, Wilson G, Ning Z, He L (2007) Potential health risk in areas of high natural concentrations of thallium and importance of urine screening. Appl Geochem 22:919-929

Yang C, Chen Y, Peng P, Li C, Chang X, Xie C (2005) Distribution of natural and anthropogenic thallium in the soils in an industrial pyrite slag disposing area. Sci Total Environ 341:159-172 